relation Between time of Reaction aND ACTivity of Tritio-

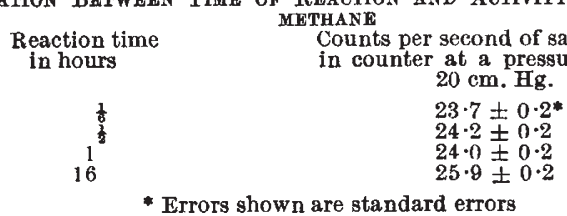

for a range of 200 volts, so that high tension need not be highly stabilized. At a pressure of $20 \mathrm{~cm}$. mercury a $200 \cdot \mathrm{ml}$. counter contains $9.4 \mathrm{mgm}$. of methane hydrogen, which is a suitable weight for estimations in many biological experiments. The counter is quite usable, however, at pressures up to $40 \mathrm{~cm}$. mercury.

Fig. 3 shows a typical relationship between recorded pulse-rate and discriminator bias, affording proof of almost complete registration of ionizing events within the sensitive volume of the counter.

The period of reaction of the water and carbide at $100^{\circ} \mathrm{C}$. was varied. The accompanying table shows that rates of reaction of $\mathrm{THO}$ and $\mathrm{H}_{2} \mathrm{O}$ at $100^{\circ} \mathrm{C}$. are not widely different. A reaction time of one hour is usually employed, since heating for shorter periods leaves droplets of water on the sides of the vessel.

Tritium activities can be estimated with a reproducibility of 2-3 per cent by pumping the methane into the counter to a pressure of $20 \mathrm{~cm}$. mercury and counting at a single voltage. The voltage is determined for each Geiger-Müller tube by inspection of the plateau.

It is difficult to decontaminate apparatus used for reduction of tritiated water to hydrogen ${ }^{1}$. With the present procedure no contamination of the counter manifold or the reaction vessels has been detected.

During the action of tritiated water on aluminium carbide some tritium will combine to form aluminium tritio-hydroxide. The ratio of radioactivity in methane to total radioactivity in the water was therefore determined. A sample of tritiated water was reduced to hydrogen by heating to $400^{\circ} \mathrm{C}$. in the presence of magnesium amalgam*. The hydrogen was then mixed with inactive methane in the proportion of $3 \mathrm{~cm}$. of hydrogen to $17 \mathrm{~cm}$. methane. The plateau of this mixture in the proportional region was quite usable although inferior to that obtained with methane. By this method it was found that approximately 50 per cent of the tritium in water allowed to react with aluminium carbide passes into methane. Since incomplete reduction of the water might have allowed isotope separation to occur, the reaction with magnesium amalgam was done for onehour and four-hour periods, but without significant difference in the results.

With previous procedures it has been recommended that water samples be purified by repeated distillations in vacuo before reduction to hydrogen'. Purification has been found to be unnecessary with the present method. A whole rat was blended, and the homogenized tissues oven-dried and combusted to water by heating in a stream of oxygen passing over red-hot copper oxide. The water was collected in a U-tube immersed in dry-ice, and no precautions were taken to prevent collection of impurities from the combustion. The water thus obtained was used for diluting a sample of tritiated water. The counting characteristics of methane derived from the diluted sample were found to be the same as those of methane derived from pure tritiated water.

With a two-inch lead screen and methane at $40 \mathrm{~cm}$. mercury pressure, the background of the counter was found to be $1 \cdot 7$ counts per second, so that samples having an activity as low as 1 count per second can be estimated. The method thus allows assay of material having a specific activity of $1.5 \times 10^{-8}, \mathrm{C}$. per mgm. of hydrogen.

We would like to thank Prof. B. S. Platt for his interest in this work. Thanks are also due to the Atomic Energy Research Establishment, Harwell, for provision of the tritium and loan of certain electronic equipment.

Kamen, M. D.. "Radioactive Tracers in Biology" (Academic Press, New York, 1947).

${ }^{2}$ Pace, N., Kline, L., Schachman, H. K., and Harfenist, M., J. Biol. Chem., 168, 459'(1947).

${ }^{3}$ Palevsky, H., Swank, R. K., and Grenchik, R., Rev. Sci. Instr., 18, 298 (1947).

4 Henriques, F. C., jun., and Margnetti, C., Indust. Eng. Chem. (Anal. Ed.), 18, 420 (1946).

${ }^{5}$ Gurin, S., and Delluva, A. M., J. Biol. Chem., 170, 545 (1947).

- Allen, M. B.. and Ruben, S., J.Amer. Chem. Soc., 64, 948 (1942); 64, $2294(1942) ; 64,3037$ (1942).

'Kemula, W. M., Przemysl. Chem., 12, 411 (1928).

s Urey, H. C., and Price, D., J. Chem. Phys., 2, 300 (1934).

\section{REHABILITATION OF DERELICT LAND}

$\mathrm{D}^{\mathrm{B}}$ ERELICT LAND' has been defined as "land which has been so damaged by extractive or other industrial processes that in default of special action it is unlikely to be effectively used again within a reasonable period and may well be a public nuisance meantime". The existence of many thousands of acres of such land-exactly how much, no one has ever calculated-in this small and crowded island of Britain creates problems of considerable magnitude. These problems are national, in the sense that every acre of agricultural land is precious, and we cannot afford either to waste agricultural land by leaving it derelict after mineral working, or to condone the encroachment by other forms of 'development' on agricultural land while the derelict areas remain unused. The problems are also, and in a much more obvious sense, local, involving considerable land-use conflicts and questions of amenity.

A recent publication by $R$. O. Whyte and J. W. B. Sisam, entitled "The Establishment of Vegetation on Industrial Waste Land"1, has summarized a large body of very scattered literature on the subject, drawn mainly from Britain and the United States; and a symposium on "Rehabilitation of Derelict Areas", held on September 5 in Sections K (Botany) and $M$ (Agriculture) of the British Association during the recent meeting at Birmingham, shed considerable further light on recent progress.

There are really two quite distinct sets of problems involved: first, following the contribution of Prof. S. H. Beaver to the symposium, there is derelict land of the type that has characterized most of the older coalfield areas of Britain for many years past-land worked over for coal and perhaps also for ironstone, and scarred by pit-mounds, subsidence hollows, slag heaps from old ironworks, and other industrial waste. It is in the Black Country of south Staffordshire and north Worcestershire-a rough quadrilateral bounded by Walsall, Wolverhampton, Stourbridge, Halesowen, and West Bromwich-that this type of surface is most in evidence: a survey made in 1945 revealed more than 9,000 acres'. A surface of 'hills-andhollows' resulting from the shallow mining of thick coal seams and numerous ironstone courses is the 
most characteristic, with relatively few large individual spoil heaps and relatively few slag heaps (for despite the large number of furnaces during the nineteenth century, most of their slag has been quarried away for road metal). Since coal-mining has been virtually extinct in the Black Country for upwards of half a century, an appreciable vegetation cover, recently studied in detail by Dr. W. J. Rees of the University of Birmingham, has developed, and many of the areas are by no means unpleasant to the eye-though they are often made less attractive by the indiscriminate dumping of miscellaneous domestic and other refuse. Similar conditions obtain in the Shropshire coalfield (the Ironbridge-Oakengates area). To a certain extent, too, comparable circumstances exist in other coalfields, though here-as in the Potteries, for example, or in south Lancashire, in west Durham, and in the north-eastern part of the South Wales coalfield-the problems are of a rather different nature, partly since much of the mining was deeper, and the spoil heaps consequently larger, and partly because nowhere outside the Black Country is derelict land so concentrated and in quite such intimate relationship to urban development.

The rehabilitation of derelict areas in the Black Country must almost inevitably be in terms of levelling for housing and industrial sites, or for playing fields and recreation grounds. The creation of agricultural land is clearly out of the question in such an environment, while tree-planting, mainly of deciduous trees, since conifers suffer from the excessive soot deposit, can at best be merely for ornamental purposes. A few small plantations exist, and there are several well-maintained parks (notably Willenhall Memorial Park) created out of old spoil heaps. The reclamation of derelict land is no new thing in the Black Country. Many of the housing and industrial developments of the twentieth century have involved building on land which has been both undermined and covered with spoil. But with the advent of the bulldozer in the mid-1930's, and more recently the tractor-drawn scraper, the task of the civil engineer has been made much easier. A revision of the 1945 survey, carried out for the West Midland Plan in the early part of 1948 , showed that in three years some 1,900 acres had been or were being reclaimed, while a further 400 acres of derelict land had been acquired by the local authorities for purposes of development -mainly temporary or permanent housing ${ }^{3}$. It is indeed a matter for great satisfaction, and reflecting credit on the eighteen local authorities concerned that, without any of the government money which has been specially available for reclamation in the so-called 'Development Areas', the problem has been so vigorously tackled.

Of an entirely different nature is the problem of the derelict surfaces created by the mechanization of certain types of quarrying operations, especially gravel digging in many parts of the country, and the excavation of ironstone in the East Midlands. The former is at present under consideration by a committee appointed by the Minister of Town and Country Planning. Several reports have been published ${ }^{4}$, and some aspects of the problem have also been discussed independently by two members of the committee ${ }^{5}$. Opencast ironstone mining, to which has been added, during the past decade, opencast coal mining, has also excited considerable public interest, especially in Northamptonshire, where the greatest damage has been done; two official documents are available ${ }^{6, ?}$, with a third emanating from the industry ${ }^{8}$, while two standing conferences, under the auspices of the Ministry of Town and Country Planning, are still at work discussing the ways and means of restoration and after-treatment.

In the symposium at Birmingham, these problems were surveyed in general terms, with special reference to the conservation and reconstruction of soil, by Sir John Russell, while Mr. R. B. Beilby, of Stewarts and Lloyds, dealt with the nature of the excavating machinery and of the surfaces produced; Mr. W. Morley Davies, of the Agricultural Improvement Council, considered the methods of bringing back devastated land into agricultural use, and Mr. R. W. B. Newton analysed the problem of afforestation.

The use of excavating machinery in the ironstone fields goes back to 1895 , but there was little intensive development until after the First World War. It is often forgotten that since the early 1850's, when ironstone digging began in Northamptonshire, at, least 10,000 acres of the mineral field have been restored to agriculture or developed in other ways, after the extraction of the ore. This was relatively easy when both ore and overburden were dug by hand, and surface soil could be repliced behind the advancing quarry face. Mechanical excavation and dumping of more than $30 \mathrm{ft}$. of overburden-and up to $90 \mathrm{ft}$. is now removed in one area-have created some 4,600 acres of derelict 'hill-and-dale', while a further 900 acres of such land has been afforested. Some 350 acres of ironstone-bearing land is now being worked each year, and the requirement for the next twenty years has been estimated at 12,800 acres. The excavators get bigger and bigger, the amplitude of the 'hill-and-dale' increases, and there is less and less economic possibility of separately removing and conserving the 'topsoil'. Until recently, the largest machines were face-shovels equipped with 9-cu. yd. buckets; the latest giant is a dragline excavator with a 282-ft. boom and a 20-cu. yd. bucket, and even larger ones are contemplated. It is true that the smaller types of 'walking dragline', operating in relatively shallow overburden of up to $35 \mathrm{ft}$., can avoid the creation of 'hill-and-dale' by casting their spoil to form a more or less level surface, but the possibilities in this direction are somewhat limited. A further very difficult problem is created by the quarries in which a large proportion of the overburden consists of the hard "Lincolnshire Limestone" formation. The 'hill-and-dale' in these circumstances is made up largely of limestone boulders, and is very difficult either to afforest or to level for agriculture.

Much has been done in Northamptonshire, by landowners and by the ironstone producers, to afforest the devastated areas; the largest firm in the field maintains its own tree nurseries and staff of foresters, and much experience has been gained. Much of the plantation has been of softwood species, notably larch and pine (and the Corsican pine seems best able to tolerate the atmospheric conditions which often prevail in areas near the iron and steel works); but hardwood trees, notably sycamore, alder, poplar and oak, have also been successful. There is in general no need to level the 'hill-and-dale' before planting; but it is important to drive level rides across plantations to facilitate planting and extraction. Rabbitproof fencing is, of course, essential.

The reinstatement of agriculture on the devastated areas is more difficult, especially when, as is usual, the surface layers of soil and subsoil have been irretrievably lost and buried during the excavating 
process. The civil engineering side of the problemit may be called simply 'muck-shifting'-presents few difficulties, with modern draglines, scrapers and bulldozers. There will, of course, be troubles arising from the uneven settlement of the levelled land, from defective drainage, and from the presence of boulders at the surface; but the major difficulty, as Sir John Russell pointed out, is the creation of a new soil out of what is virtually unadulterated rock, devoid of humus and of organic life, with no crumb-structure, and deficient in many of the chemical elements which contribute to plant growth. Much experimental work has been carried out in recent years by the ironstone producers and by the Ministry of Agriculture on levelled surfaces of different geological constitution, in order to ascertain the most appropriate methods of cultivation, pioneer and subsequent crops, and fertilizers. The fertilizers required naturally vary with the geological nature of the rock which now forms the surface, but usually there are marked deficiencies of phosphate, potash and nitrogen. The most useful pioneer plants are lucerne and clover, while of the grasses, ryegrass, cocksfoot, timothy and meadow fescue have all been grown with success; even wheat has been grown in the third year after restoration. A most striking fact is the complete absence of weeds-a great contrast with areas in which the soil has been conserved and replaced!

In opencast coal excavations, agricultural restoration, with replacement of soil, has been practised from the very beginning, with variable results. The economic circumstances, however, are rather different from those of the ironstone industry. Nevertheless, it is interesting to note that a recent Order by the Minister of Town and Country Planning has made soil conservation and agricultural restoration compulsory in all ironstone quarries in which the overburden consists of less than $35 \mathrm{ft}$. of material which is not mainly limestone-though it must be admitted that such quarries are relatively few in number, and that in many of them, as in Oxfordshire and in south Lincolnshire, agricultural restoration has in any event been customary since the quarrying began.

One vital matter, which was not mentioned. by any of the speakers but which emerged during the discussion, is that there-is a financial side to all these problems. Someone has to pay for the levelling and other after-treatment of derelict and devastated land, and it is by no means easy to see who should foot the bill. As Sir John Russell, Prof. Dudley Stamp and others have repeatedly reminded us, however, our one ultimate asset is our land, and it is our duty to hand down this heritage to future generations in a utilizable and not in a derelict condition.

\section{S. H. Beave}

${ }^{2}$ Whyte, R. O., and Sisam, J. W. B.; "The Establishment of Vegetation on Industrial Waste Land" (Commonwealth Agric

Beaver, S. H. "Report on Derelict Iand in the Black Country". (Ministry of Town and Country Planning, 1946.)

3 West Midland Plan, prepared for the Minister of Town and Country Planning by Sir Patrick Abercrombie and Herbert Jackson, 1948. Section II, Chap. 2, par. 126-147, by $\mathrm{S}$. H. Beaver.

- Report of the Advlsory Committee on Sand and Gravel. Part I, General Survey, Part II, Greater London (H.M.S.O., 1948). Part III, West Midlands, Part IV, East Midlands (H.M.S.o. 1950). Part , Wessex (t.M. M.

Wooldridge, S. W., and Beaver, S. H., Geog. J., 45, 42 (1950).

- Report of the Committee on the Restoration of Land affected by Iron Ore Working. (H.M.S.O., 1939.)

'Report on the Restoration Problem in the Ironstone Industry of the Midlands. Cmd. 6906. (H.M.S.O., 1946.)

"Memorandum dealing with the working of stratifled ironstone in the Jurassic system fo England." Na

\section{PARSONS MEMORIAL WINDOW IN WESTMINSTER ABBEY}

ATER the death in 1931 of Sir Charles Parsons, the Royal Society set up a committee to arrange an appropriate memorial of which a memorial window in Westminster Abbey was to be one part. Another is the Parsons Memorial Lecture delivered annually. A third was the contribution of $£ 10,000$ towards the Parsons Memorial Library at London House, Bloomsbury, which was opened by Their Majesties the King and Queen on December 3, 1937. The suggestion for a memorial window was favourably received by the Dean and Chapter of the Abbey, and it was agreed that its execution should be delayed for some years. The window has now been completed, to the design of Sir Ninian Comper, and was dedicated by the Dean of Westminster on October 5 , on the invitation of Sir Robert Robinson, president of the Royal Society, before a large gathering including many members of the Parsons family and representatives of the Royal Navy and of the scientific and professional bodies and industrial concerns with which Sir Charles Parsons had been associated.

It is in the north side of the nave, next to that commemorating the engineer John Wolfe Barry, and near neighbours are those to Benjamin Baker and Lord Kelvin.

The memorial oration was delivered by Sir Frank Smith, chairman of the Royal Society memorial committee and himself the first Parsons Memorial Lecturer. Sir Frank sketched Parsons's early life and unusual upbringing as the sixth son of the third Earl of Rosse, who built in his own home at Parsonstown, Ireland, his famous reflecting telescope. He continued :

"The eighteen eighties were critical years for Parsons. They were also his years of triumph. At that time the gas engine was challenging the supremacy of steam in prime-movers. The generation of electricity by dynamos together with the ease of its transmission threatened the methods then in use for transmitting power. . . . In this maze of primemover problems and power transmission systems Parsons saw a great opportunity to solve both problems by developing an efficient rotary steam engine or turbine coupled directly to a high-speed dynamo. In this way he believed that steam would maintain its supremacy and that electricity would be generated at a reasonable price. To use his own words: 'I determined to attack the problem of the steam turbine and of a very high speed dynamo and alternator to be directly driven by it'.

"In choosing this objective Parsons was, I, think, inspired by three main influences: the first and greatest was his love of attempting what others thought impossible; the second was his extra. ordinary knowledge of thermodynamics; and the third, his ambition to produce an economic rotary steam engine.

"A rotary steam engine was no novelty, but in practically all such machines the steam after expansion was ejected in a hurricane of vapour from which only a small part of the energy had been extracted. When allowed to expand freely high-pressure steam develops enormous velocities, and it was easy for Parsons to calculate that a turbine blade tip would need to move with a velocity exceeding that of sound to extract most of the energy from such steam. This was the first obstacle to be overcome. After a vast 